Interconnecting Scientific World

Research Article

Open Access

\title{
Use of Cooperative Game theory in day-to-day Farmer Producer Organization's Operations
}

\author{
Veerin Kumar Rama ${ }^{1}$ and M.V. Durga Prasad ${ }^{2 \star}$ \\ ${ }^{1}$ Associate Professor, Food \& Agri Business School, Flame of Forest, Urella Road, Chevella, Hyderabad, India \\ ${ }^{2}$ Freelance Researcher, India
}

\section{Article Info}

\section{*Corresponding author: \\ M.V. Durga Prasad \\ Freelance Researcher \\ Department of Agriculture \\ India \\ Tel: + 919724503902 \\ E-mail: dprasador@gmail.com}

Received: October 29, 2021

Accepted: November 17, 2021

Published: November 23, 2021

Citation: Rama VK, Durga Prasad MV. Use of Cooperative Game theory in day-to-day Farmer Producer Organization's Operations. Madridge J Agric Environ Sci. 2021; 3(1): 60-63

doi: $10.18689 /$ mjaes-1000111

Copyright: ( $) 2021$ The Author(s). This work is licensed under a Creative Commons Attribution 4.0 International License, which permits unrestricted use, distribution, and reproduction in any medium, provided the original work is properly cited.

Published by Madridge Publishers

\begin{abstract}
Farmer Producer Organization (FPO), relatively new concept in India, pioneered by Small Farmers' Agri-Business Consortium (SFAC), promoted by Department of Agriculture Cooperation and Farmers welfare, Ministry of Agriculture and Farmers Welfare, Government of India. Later this concept successfully implemented by several institutions, which are working directly with the farmers. It observed that there exists some challenges on the issues of quality of goods related to price when collective action takes place. An attempt made in this work to initially represent the problem mathematically and use the right methods viz. well known solution concepts of cooperative game theory.
\end{abstract}

Keywords: Producer; Cooperative games; Quality; Price; Buyer

\section{Introduction}

To build a prosperous and sustainable agriculture sector by promoting and supporting member-owned Producer Organizations, that enable farmers to enhance productivity through efficient, cost-effective, pricing and sustainable resource use and realize higher returns for their produce, through collective action supported by the government, and fruitful collaboration with academia, research agencies, civil society, and the private sector. To promote economically viable, democratic, and self-governing Farmer Producer Organizations (FPOs) [1-6]. Small Farmers'Agri-Business Consortium (SFAC), promoted by Department of Agriculture, Cooperation and Farmers welfare, Ministry of Agriculture and Farmers Welfare, Government of India, had pioneered the concept of FPO and later implemented by several institutions which are working directly with the farmers.

The underlying rationale for the development of FPOs is the typical fragmented and small size of land holdings of farmers in India. With typical holdings of less than 1 hectare, farmers cannot individually enjoy economies of scale and afford to invest in farm mechanization/technology for enhancing farm productivity, nor optimally procure inputs nor directly access buyers. Aggregation through FPOs is the only feasible option left for farmers to enhance their bargaining power and farm-related value accruals, as has also been established through various programs [7,8].

NABARD is another agency supported FPO's in formation of groups as well as providing financial aid and establishing necessary infrastructure. Farmer Producer Organisation (PO) is a legal entity formed by primary producers, viz. farmers, milk producers, fishermen, weavers, rural artisans, craftsmen, etc. Producer Organisations have been considered one of the effective means of linking small producers with the 
agricultural value chain for enhancing net income of producers. NABARD provides financial and development support to FPOs [9].

e-NAM is one agency which encourages FPO's to use their digital marketing platform. The role of FPO is to act as an aggregator for member farmers including from inputs to output that will enhance the economy of scale and bargaining power of member farmers. In case of unsold Lots, Logistics arrangement is to be made by FPO [10].

To provide support for the promotion of such FPOs by qualified and experienced Resource Institutions. To provide the required assistance and resources - policy action, inputs, technical knowledge, financial resources, and infrastructure to strengthen these FPOs. To remove hurdles in enabling farmers to access the markets through their FPOs, both as buyers and sellers. To create an enabling policy environment for investments in FPOs to leverage their collective production and marketing power [11].

The formation and development of FPOs will be actively encouraged and supported by the Central and State Governments and their agencies, using financial resources from various centrally sponsored and State-funded schemes in the agriculture sector agencies. This goal will be achieved by creating a coalition of partners by the concerned promoter body, involving civil society institutions, research organizations, consultants, private sector players, and any other entity that can contribute to the development of strong and viable producer-owned FPO [12-16].

In this research paper the concepts of cooperative game theory and its solution [17-22] are used to analyzed the interpretation of FPO operations employed in this section Analyses with mathematical formulation and derivation.

It was observed that any commodity (particularly for fruits $\&$ vegetables) to sell in the market collectively will have some challenging issues besides the monetary benefits being positive. The challenging issues can be expressed in the following problem [23-25].

\section{Problem identification}

In farmer producer organizations (FPO), though individual members will gain in collective marketing but comparing revenues among them in collective action versus individual action, there exists some gap in it. Buyers often complaint to the government marketing committee officials that quality of the produce is not upto their expectation in order to have smooth movement in the downstream flow of the supply chain. However, producers feel that the price they receive is not up to their expectation. So quality dependent price for any agricultural commodity identified as the primary problem. This price meant for producers.

\section{Analyses with mathematical formulation and derivation}

Deal the dilemma mentioned in the above section regarding expectation of buyers and producers with the wellknown commodity's successful implementation. The wellknown commodity is none other than milk. In milk cooperatives operating in India, the expectation of producers regarding price met with one parameter and acceptance of the milk related to quality met with another parameter. Such acceptance will ensure the buyer's expectation regarding quality of all the products obtained through production by using the raw milk. Similar operations for all agricultural commodities through an important institution viz. Farmer producers' organization (FPO's). These FPO's will act as intermediary platform between sellers (farmers) and buyers.

Mathematical model development: In a particular FPO, there may exist $n$ producers for a particular commodity. Let $\mathrm{P}_{1^{\prime}}, \mathrm{P}_{2^{\prime}},---, \mathrm{P}_{\mathrm{n}}$ represent $\mathrm{n}$ producers who bring a particular commodity (ungraded) to the market with units $\alpha_{1}, \alpha_{2^{\prime}}---, \alpha_{n}$ The quality of the commodity can be of 4 types' viz. extremely good quality $\mathrm{Q}_{1}$, Very good quality $\mathrm{Q}_{2^{\prime}}$ Good quality $\mathrm{Q}_{3^{\prime}}$ and satisfactory quality $Q_{4}$. Quality function $Q$ with inputs being producer $\mathrm{P}_{\mathrm{i}}$ and outcomes will be one of the four qualities $\mathrm{Q}_{1^{\prime}}$ $\mathrm{Q}_{2}, \mathrm{Q}_{3}$ and $\mathrm{Q}_{4}$. If require, divide these quality grades further in order to lower the quality grade variance within the quality of the commodity from the producers in a particular category. Mathematically if there exists $m$ types of quality then it can be expressed as $\mathrm{Q}_{1}, \mathrm{Q}_{2^{\prime}}----\mathrm{Q}_{\mathrm{m}}$. As the price associated with the parameters related to quality, it is important to ensure less variation among the prices for producers. In milk commodity, such categorization is not required due to the liquefied form of the commodity. Define the $\mathrm{Q}$ function as follows:

$Q\left(P_{i}\right)=Q_{i} k . i=1,2,---, n$ and $k$ takes one of the values $1,2,3,4$ if there are four types of quality and in case of $m$ types of quality, its function can be defined as

$Q\left(P_{i}\right)=Q_{i} k . i=1,2,---, n$ and $k$ takes one of the values 1,2,3,-----, $m$

In any case, total volume of a commodity brought to the market $=\sum_{i=1}^{n} \alpha_{i}$ and total volume of a commodity belongs to a particular quality $j$ can be expressed as $\sum_{i=1}^{n} \alpha_{i 2}$ for example if $\mathrm{j}=2$ then total volume of a commodity can be expressed as $\sum_{i=1}^{n} \alpha_{i j}$ In the given expression it will add only if i2 exists for any $\mathrm{i}=1,2,---, \mathrm{n}$. In fact $\sum_{i=1}^{n} \alpha_{i}=\sum_{k=1}^{m} \ldots . . . \sum_{i=1}^{n} \alpha_{i k}$

where $\alpha_{i l}=\alpha_{i}$ if producer $i$ supply a quality l otherwise it takes value 0

In order to bring a win-win situation for both FPO as well as an institutional buyer, FPO accept the quoted price by institutional buyer in order to match a right price for producers. On the contrary, acceptance of price fixed by an institutional buyer is not automatic from the producers under FPO's unit. Each producer will have his own thought process in analysing the price obtained versus quality of the product given to FPO. Milk under this process is partly successful due to the existence of an equipment measures the quality as well as the right functional relationship between measurement of quality and price associated for both producers as well as for the societal institution. For the price to producers, payment will be from the society whereas for the price to the society, the processing unit pays it. For agricultural commodity processing unit is absent unless margins through marketing of processed products are higher than that of graded raw material. Some societies have agricultural commodity processing facility due to margins are always higher in case of 
pulses and some other commodities. However, one of the targeted institutional buyer can be processor during low market season for fruits and vegetables. For most of the perishable agri goods, processors utilise their processing facility only if they get raw material at low price i.e., during low market season. Some institutions have a processing facility in an urban places where farmers can utilise the facility with free of cost. For some commodities, such facilities are essential because they utilise only during low market season. As it is a well-known fact that milk cooperatives in India formed to maximize the bargaining power for the producers, farmer's producer organization formed to obtain similar benefits.

\section{Calculation of sharing benefits among members under FPO}

If we categorize the entire collection of a particular commodity into $\mathrm{m}$ sets with respect to quality and the amount $a_{1^{\prime}} a_{2^{\prime}},--, a_{m}$ relates to the price per unit for the respective quality category then total revenue obtained by selling such $\mathrm{m}$ categories of quality supply from the producers to the institutional buyer/s will be

$$
\sum_{k=1}^{m} a_{k} \sum_{i=1}^{n} \alpha_{i k}
$$

Values of each producer $i$ be denoted by $V\left(P_{i}\right)$ which can be evaluated as

$\sum_{k=1}^{m} \alpha_{i k} \alpha_{k} \ldots: \mathrm{i}=\mathrm{V}\left(\mathrm{P}_{\mathrm{i}}\right)$

Note: Here $a_{i}$ is the price quoted by institutional player on that day of the unit commodity produced by $\mathrm{P}_{\text {.i. }}$. Price on any day will depend upon the supply and demand to the market as well as the quality parameters.

If $a_{i}=200$ units and $\alpha_{i k}=217$ amount obtained per unit of supply then value of $\mathrm{i}^{\text {th }}$ producer will be equal to

$$
V(P i)=200 * 217=43400
$$

Value of each producer $\mathrm{V}(\mathrm{P} 1), \mathrm{V}(\mathrm{P} 2),----, \mathrm{V}(\mathrm{Pn})$ can be calculated similarily.

P1, P2, ----, Pn together brought a volume of $\sum_{i=1}^{n} \alpha_{i}$ units to the market and obtained individually some values according to their quality of goods.

In absence of markets, total goods mix with different quality parameters can be combined together to sell to an institutional buyer.

By using cooperative game theory, one can calculate the share of each producer

If all the $\mathrm{n}$ membersdivided into $\mathrm{m}$ categories according to the quality of good brought to the market then total revenue obtained by getting goods together will have more impact when compared to other coalitions provided number of divisions is optimal number with the low variance in quality within the category itself.

This will imply all coalitional values of two together; three together etc will not be effective. i.e., $\mathrm{V}(\mathrm{Pik}, \mathrm{Pjk})=\mathrm{V}(\mathrm{Pik})+\mathrm{V}(\mathrm{Pjk})$. Logically it is true that if coalitional value of two producers has a positive increase in the right hand side of the mentioned equation then those two producers need not join the FPO. Whereas grand coalition of volumes of all $n_{k}$ producers for the $k_{\text {th }}$ quality category will be able to sell to the institutional buyer in order to get the benefit for all producers who brought the respective quality $k$ commodity.

Sharing of such benefit through collective action will be done through the solution concept of cooperative game theory for transferable utility [17-22].

In absence of FPO, producers will individually sell at the markets without grading in terms of size. But in order to sell it to institutional buyer like big basket etc, they have to grade it to a uniform size. Hence the market value of the commodity produced by $P_{i}=\alpha_{i}{ }^{*} b_{i}$ where $b_{i}$ is the price on that day of the unit commodity produced by $P_{i}$. Price on any day will depend upon the supply and demand to the market as well as the quality parameters.

Grand coalition value of the $n$ players formed to become FPO can be obtained by selling the mixed graded commodity to a particular business unit like big basket to get profit.

Producers benefit obtained by such collective action (PB) $=\rho\left(\sum_{k=1}^{m} \ldots: \sum_{i=1}^{n} \alpha_{i k} *\left(\alpha_{k}-\mathrm{FCh}\right)\right)-\sum_{i=1}^{n} \alpha_{i} * b_{i}+(1-\rho) * \sum_{i=1}^{n}$ $\left.\alpha_{i}\right) * b_{i}$

where $\rho$ stands for reduced weight after grading to uniform size and $0<\rho<1, F C h$ is the charges per unit prescribed by FPO and $b$ is the price per unit at the market for the remained commodity after grading at the farm level. If benefit value is positive then collective action becomes meaningful.

Individual Producer $P_{i}^{\prime}$ s revenue by collective action = $\alpha_{i}^{*} b_{i}+(1 / n)^{\star} P B$ if the solution concept nucleolus chosen [22]. Quality category wise benefit can also be calculated if the F-Nucleolus concept chosen [17].

Alternative approach for quality categorization be possible through an innovative machine, which will define the price according to the color and average size of the raw material. Besides these two attributes, machine can also identify other attributes like texture and density. Though these two attributes may not directly influence the price but it can eliminate some percentage of wasted raw materials that do not meet the requirements of such attributes. Once allowable limits are defined for each attribute irrespective whether they influence the price or not, machine will separate wasted material and quality material. Such machines should support with the capital cost, which is feasible for the buyer/ FPO's to purchase since government encourages such organizations through either loan or subsidy.

\section{Conclusions}

Forming an FPO shows benefits for producers. Two important parameters viz. price and quality shown to be useful in obtaining benefits to both stakeholders. Agri commodities compared with the well-known milk cooperatives in India to apply a suitable research method. Once the qualitybased priceemployed, there is a likelihood of improvement in quality of supply at subsequent periods. 


\section{References}

1. FAO-ILO. 'Cooperatives \& Producers' Organizations: Food, Agriculture. 2014.

2. Kenderdine T. Insurance Plus Futures: Agricultural Commodity Price Reform in China. Asia \& the Pacific Policy Studies. 2018; 5(2): 331-346. doi: 10.1002/app5.226

3. Ogunleye AA, Oluwafemi, Zacchaeus $\mathrm{O}$, Arowolo KO, Odegbile OS. Analysis of socio economic factors affecting the participation in cooperative societies in surelere local government area of Oyo state. Journal of Agriculture and Veterinary Science. 2015; 8(5): 40-44.

4. Salokhe $\mathrm{S}$. Farmer producer organization for effective linkage of small producers with market. Int J Appl Res. 2016; 2(10): 142-146.

5. Venkattakumar R, Mysore S, Venugopalam R, et al. Performance of farmer producer organizations (FPOs and associated factors in karnataka): Producers'perspective. Indian Research Journal of Extension Education. 2019; 19(2\&3): 7-12.

6. Mahajan V. "Farmers' Producer Companies: Need for Capital and Capability to Capture the Value Added," in S. Datta, V. Mahajan, Ratha et al. (eds), State of India's Livelihoods Report 2014 (New Delhi: Oxford University Press, pp. 87-108); N. Srinivasan, "Farmer Producer Organizations," in N. Srinivasan and G. Srinivasan (eds), State of India's Livelihoods 2017, (New Delhi: Sage Publications, 2018), pp. 141-176.

7. Shirish Joshi. "Farmers' Producer Organizations (FPOs) in Rainfed Areasan Alternative," 2019; Note prepared for the Revitalising Rainfed Areas Convention, February, 13-14 (New Delhi: India International Centre, 2019). Shirish Joshi's paper (2019) at the RRA convention has been followed with discussions in smaller groups on the ASC model. An abridged version has been reproduced here.

8. http://sfacindia.com/UploadFile/Statistics/Strategy-Paper-onPromotion-of-10,000-FPOs.pdf

9. https://www.nabard.org/content.aspx?id=470

10. https://enam.gov.in/web/stakeholders-Involved/fpos

11. https://www.researchgate.net/publication/330507905_Financing_ nascent_Farmer_Producer_Organisations_FPOs

12. http://sfacindia.com/List-of-FPO-Statewise.aspx

13. http://mofpi.nic.in/sites/default/files/fpo_policy_processguidelines_1_ april_2013.pdf

14. http://www.thehindubusinessline.com/industryand-economy/advisorycouncil-urgesgovt-to-promote-farmer-producerorganisation/ article4361525.ece.
15. The Ministry of Corporate Affairs has consolidated information until 2016 and month-wise data from 2016-19 has been used to collate this data. This information does not include inactive FPCs and that is likely to bring down the numbers. The author would like to thank Tushar Garg and Abhishek Saxena for assistance in compiling and analysis.

16. https://www.thehindubusinessline.com/economy/budget/budget2019-farmer-producer-organisationsrequire-ecosystem-of-support/ article28302920.ece.

17. Durga Prasad MV, Saloman Danaraj RM. F-Nucleolus of Cooperative Games: An approach for affair allocation, Vision 2020: The strategic role of operational research, Proceedings of the annual Operations Research Society of India conference held at IIM, Ahmedabad, India, 2005; 313320.

18. Durga Prasad MV. Public transport and cooperative TU games: A case study of Asmara city, The ICFAI journal of Science \& Technology II(no.1), 2006; 70-79.

19. Durga Prasad MV. Automation of modified marketing procedural system to maximize transparency: A case study of vegetables in Madanapalle market. Journal of Agribusiness in Developing and Emerging Economies. 2016;6(1):72-88. doi: 10.1108/JADEE-08-2014-0027

20. Durga MV. An Efficient Algorithm for solving Nucleolus of cooperative TU Games using MATLAB. International Journal of Innovative research and development. 2016; 5(8):

21. Faigle U, Kern W, Fekete SP, Hochstattler W. The Nucleon of Cooperative Games and an algorithm for matching games. Mathematical Programming. 1998; 83(1-3): 195-211. doi: 10.1007/BF02680558

22. Schmeidler $D$. The nucleolus of a characteristic function game. SIAM Journal of Applied Mathematics. 1969; 17(6): 1163-1170. doi: 10.1137/0117107

23. Nayak AK. "Farmer Producer Organizations in India: Policy, Performance, and Design Issues", in N.C. Rao, R. Radhakrishna, R.K. Mishra and V.R. Kata (eds), Organised Retailing and Agri-Business (New Delhi: Springer India); Singh and Singh, Producer Companies in India. 2016.

24. Subhangi S. Farmers Producer Organization for effective linkage of small producers with market. International Journal of Applied Research. 2016; 2(10): 142-146.

25. Policy and process guidelines for Farmers Producer Organizations, Department of Agriculture and Cooperation. 2013, Ministry of Agriculture, Government of India. 